\title{
Ownership of parrots in Madagascar: extent and conservation implications
}

\author{
Kim E. Reuter, Lucia Rodriguez \\ SaHondra Hanitriniaina and Melissa S. Schaterer
}

\begin{abstract}
The trade of live parrots is a threat to wild populations but is understudied. Madagascar is home to three parrot species listed on CITES Appendix II: Coracopsis nigra, Coracopsis vasa and Agapornis canus. Prior to this study there were no data on the ownership of parrots in Madagascar. We therefore aimed to investigate the extent of the domestic pet trade in this group. Our objectives were to quantify the prevalence, spatial extent, and timing of ownership. We collected data in July and August 2016 in nine urban towns across Madagascar, using semi-structured household surveys $(n=440)$. We found that the ownership of pet parrots is widespread in time and space; $37 \%(95 \% \mathrm{CI}$ 26-48\%) of interviewees had seen, and $8 \%$ (95\% CI 3-13\%) had owned, a Coracopsis sp. Fewer interviewees (4.5\% of all interviewees) had seen A. canus in captivity, and only one individual reported having previously owned an A. canus. We estimate that 1,290 Coracopsis spp. individuals were held in captivity in the towns surveyed, in the 1.5 years prior to our interviews. It is likely that much of this ownership is illegal, although we did not examine this explicitly. Additional research is needed to determine whether current extraction rates are sustainable. This study adds to a growing body of evidence that the domestic regulation of the trade of wild species is not being addressed adequately in Madagascar.
\end{abstract}

Keywords Africa, Agapornis canus, birds, Coracopsis nigra, Coracopsis vasa, Madagascar, parrots, trade

\section{Introduction}

$\mathrm{O}$ verexploitation is a threat to biodiversity (Baillie et al., 2004), with up to 4 million birds extracted alive from the wild annually (Karesh et al., 2005). Parrots (Psittaciformes) are no exception; the trade in live parrots is a threat to wild populations in many countries where they are endemic (Pires, 2012). Parrot populations across Africa are declining (Martin et al., 2014); in many cases

KIM E. ReUTER (Corresponding author) Conservation International, Africa Field Division, Nairobi, Kenya. E-mail kimeleanorreuter@gmail.com

Lucia Rodriguez and Sahondra Hanitriniaina Pet Lemur Survey Initiative, housed by the University of Utah, Salt Lake City, Utah, USA

Melissa S. Schaefer University of Utah, Salt Lake City, Utah, USA, and Salt Lake City Community College, Salt Lake City, Utah, USA

Received 2 February 2017. Revision requested 29 March 2017. Accepted 31 May 2017. First published online 2 October 2017. they are extracted from source countries for international pet markets (Poole \& Shepherd, 2017). In Ghana, 90-99\% of grey parrots Psittacus erithacus have been lost since 1992 as a result of the trade in these species and habitat degradation (Annorbah et al., 2016). Likewise, in the Democratic Republic of Congo the live capture of parrots for the pet trade is a driver of the decline in P. erithacus (Hart et al., 2016). Although numerous studies have examined the keeping of parrots as pets in Latin America, there have been relatively few studies of this in Africa.

Madagascar is home to three species of parrot: the lesser vasa parrot Coracopsis nigra, the greater vasa parrot Coracopsis vasa and the grey-headed lovebird Agapornis canus. There are no published population estimates for the three species, but all are thought to have at least 10,000 mature individuals in the wild (BirdLife International, 2016a,b,c). The live capture of parrots as pets in Madagascar has received scant attention (Martin et al., 2014), although other species are known to be threatened by live capture (Andreone et al., 2005; Schwitzer et al., 2013; Reuter et al., 2016).

Most documented captures of live parrots in Madagascar are anecdotal (McBride, 1996), outdated, or related to the legal export of live birds (UNEP-WCMC, 2016). In the past there were reports from north-east Madagascar of wildcaught Coracopsis spp. being held prior to export for the international pet trade (McBride, 1996), as well as in Antananarivo and around Tôlanaro for the domestic pet trade (C. vasa, Ekstrom, 2004; Coracopsis spp., Bollen \& Donati, 2006). Evidence suggests that pet parrots within Madagascar are usually taken from the wild (as opposed to being bred in captivity; K. Reuter et al., unpubl. data; UNEP-WCMC, 2016).

Similar to other developing countries (Jepson \& Ladle, 2009), there is little information regarding the trade and keeping of parrots as pets within Madagascar's national boundaries. There are no data on the frequency of pet parrot ownership within Madagascar, and estimates of extraction are typically based on export data in the CITES database (Table 1). However, in the absence of significant international export (see Methods), there is a need for estimates of domestic extraction. Understanding the domestic pet trade is important for conservation programming. We aimed to investigate the ownership of pet parrots (C. nigra, C. vasa, A. canus) in Madagascar. Our objectives were to quantify the prevalence, spatial extent and timing of ownership. Based on identified gaps in the literature, we aimed to quantify (1) the proportion of households that owned a parrot or 
TABLE 1 Number of individuals of Coracopsis nigra, C. vasa and Agapornis canus exported from Madagascar since 1981, including the number of parrots that were recorded as being wild caught (UNEP-WCMC, 2016).

\begin{tabular}{lll}
\hline & $\begin{array}{l}\text { No. of exported } \\
\text { individuals recorded } \\
\text { as wild caught }\end{array}$ & $\begin{array}{l}\text { Total no. of } \\
\text { individuals exported } \\
\text { from Madagascar }\end{array}$ \\
\hline Coracopsis nigra & 2,606 & 5,875 \\
Coracopsis vasa & 570 & 4,242 \\
Agapornis canus & 54,469 & 117,549 \\
\hline
\end{tabular}

had knowledge of parrot ownership, and (2) the occurrence of ownership in living memory. We estimated the number of Coracopsis spp. individuals extracted for pet ownership in urban areas of Madagascar.

\section{Study area}

The nine towns selected for surveying included five of the seven largest towns in Madagascar and the three in which published anecdotes indicated that Coracopsis spp. were kept as pets in the past (McBride, 1996; Ekstrom, 2004; Bollen \& Donati, 2006). The towns are located in four of the country's six provinces, and across all towns at least six ethnicities are represented. The combined human population of the nine towns surveyed was c. 1.71 million, out of Madagascar's total urban population of 7.27 million (UNDP, 2013). Madagascar's total population is c. 24.89 million people (World Bank, 2016). We acknowledge that the survey effort could have both excluded and overrepresented hotspots for parrot ownership. By selecting areas where parrot ownership had been reported previously in the literature, the sample could have been biased towards areas with higher ownership rates. However, there are areas now known to the authors (e.g. Antsiranana) where parrots have been seen as pets but not reported in the literature, and therefore this study could also have excluded areas where parrot ownership is popular but not previously known. Limited time and resources precluded surveying of more areas.

\section{Methods}

\section{Study species}

Coracopsis vasa (categorized as Least Concern on the IUCN Red List, but with a decreasing population; BirdLife International, 2016c) is a frugivore/granivore that feeds in primary and secondary forests (Bollen \& Elsacker, 2004; Reuter, 2015). The species is edge-sensitive (Watson et al., 2004). It is found in coastal regions, with a large range that includes much of Madagascar $\left(928,000 \mathrm{~km}^{2}\right.$ across both Madagascar and the Comoros; BirdLife International, 2016c).

Coracopsis nigra (Least Concern; stable population size; BirdLife International, 2016b) is a frugivore/granivore that feeds in primary and secondary forests on ripe and unripe fruit (Bollen \& Elsacker, 2004; Reuter, 2015). In one study the species was not found in edge or matrix habitats (Watson et al., 2004); other reports have found it in agricultural settings, forests, grasslands and savannahs (BirdLife International, 2017b). The range of C. nigra is recorded as the entire island of Madagascar $\left(689,000 \mathrm{~km}^{2}\right.$; BirdLife International, 2016b).

Agapornis canus (Least Concern; stable population size; BirdLife International, 2016a) is a frugivore/granivore (Collar, 1997) found in coastal regions, with a large range that includes much of Madagascar $\left(689,000 \mathrm{~km}^{2}\right.$; BirdLife International, 2016a). In one study the species was not found in edge or matrix habitats (Watson et al., 2004), although other sources indicate it is found in agricultural landscapes, savannahs and shrublands but not typically in forests (BirdLife International, 2017a).

All three study species are listed in Appendix II of CITES (2017).

Legality of capture, keeping and trade of wild parrots

Within Madagascar a 2006 law determined that species listed in Appendix II of CITES (2017) can be extracted (captured or hunted) legally only with a permit and within national quotas determined by the government (Durbin, 2007). Some have interpreted the law to mean that extraction is further restricted to national hunting seasons (Randrianandrianina et al., 2010). Similar to bushmeat hunting (Golden et al., 2014; Reuter, 2015), it is likely that most extraction occurs without permits and is therefore illegal. Prior to 2006, C. nigra was listed as a pest species and could be hunted legally in the event of human-wildlife conflict (Ekstrom, 2004).

Export of these species from Madagascar is regulated (CITES, 2008). A moratorium on trade of C. vasa was issued in 1995 (Dowsett, 2000) after the government was unable to establish export quotas (although the primary threat to the species appeared to be habitat degradation; CITES, 2008). It was later recommended that this trade moratorium be lifted, given the low demand for the species from the pet trade (CITES, 2008). There have been no reported exports of the species from Madagascar since 2000 (UNEP-WCMC, 2016). Regarding C. nigra, there have been no exports of the species since 2006, prior to which wild-caught individuals were exported for commercial reasons (UNEP-WCMC, 2016). Agapornis canus captured from the wild continue to be exported for commercial reasons ( 750 individuals in 2013 and 300 in 2014; UNEP-WCMC, 2016); an annual export quota 
of 3,500 individuals was established in 1993 (CITES Notification No. 744) but was exceeded in the 5 years that followed (Species Survival Network, 2001). There is little evidence of substantial illegal export of the three species; a public database on illegal animal seizures did not list Madagascar's parrot species (Wildlife Trade Tracker, 2016).

\section{Data collection}

We collected data in July and August 2016 in 440 households in nine towns across central, southern and eastern Madagascar, using semi-structured household surveys (Fig. 1; Table 2). Towns were selected at regular intervals along a $747 \mathrm{~km}$ highway transect (following Reuter et al., 2016), beginning in Toamasina (eastern Madagascar) and travelling in a south-central direction via the $\mathrm{RN}_{2} / \mathrm{RN}_{7}$ roads down to the town of Fianarantsoa. The town of Tôlanaro was not sampled using our overland transect approach because of safety concerns regarding travel by car.

Based on Madagascar's urban population and mean household size (4.4 people per household; INSTAT \& ORC Macro, 2005), there are c. 1,652,272 urban households in the country. It was therefore calculated that a minimum of 384 household interviews would yield a nationally representative dataset of urban Malagasy households (following Dillman, 2014; P set to 50\%; margin of error $\pm 5 \%$ of the estimate; $95 \%$ confidence level).

Verbal informed consent was received. Interviews were conducted by a two-person team of one international project leader (KER, LR, MSS) and one trained Malagasy translator ( $\mathrm{SH}$, see Acknowledgements). Following Reuter et al. (2016), we used random sampling stratified by administrative unit, with 5-10 interviews conducted within each of as many communes/quarters within each town as time would allow. To ensure independent sampling, only one adult was interviewed per household. If an eligible individual refused to participate or if nobody was present, sampling continued at the next household. Interviews were anonymous and no identifying information was collected.

Interviewees were asked the following questions: (1) Have you ever seen a pet parrot? (2) If so, where, when and how many did you see? We used various local words for parrots and lovebirds separately, as grey-headed lovebirds were not typically considered to be parrots by respondents. Translators were fluent in the local dialect and ensured that the most appropriate common names were used. We excluded wild parrots or those seen in zoos, as this study was focused only on the ownership of parrots as pets. Noting that most pet parrots in Madagascar were probably extracted illegally (even if people were not aware that it was illegal; Keane et al., 2011), and following other survey efforts in Madagascar regarding both legal and illegal behaviour (e.g. Reuter, 2015), we did not ask individuals directly

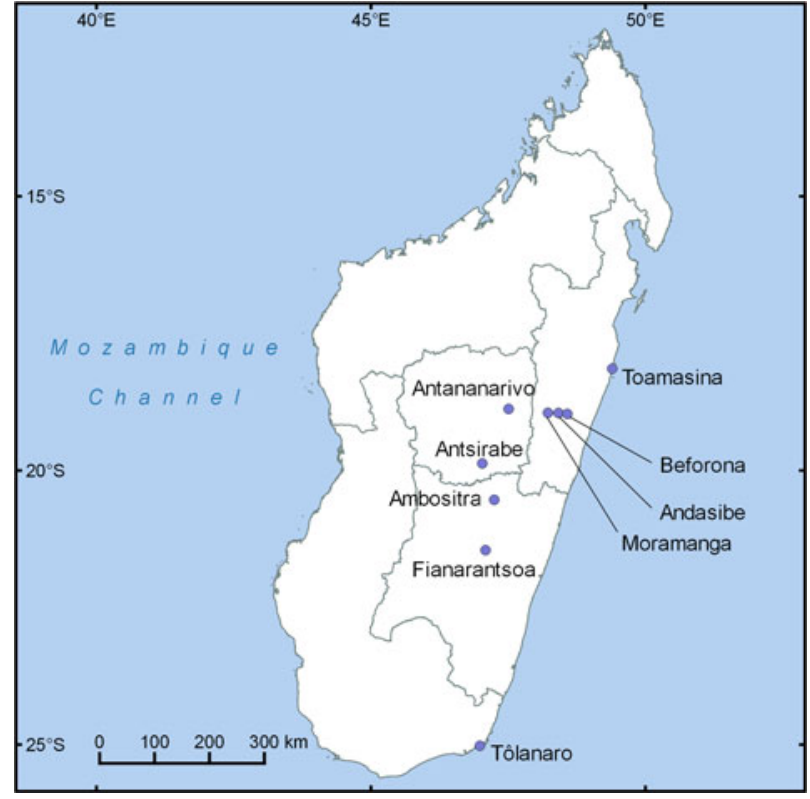

FIG. 1 The provinces of Madagascar and the nine towns where interviews were conducted to investigate parrot ownership.

about whether they had owned a parrot, because of the potential for increased interviewee discomfort. Some interviewees indicated voluntarily that they were current or former owners. Therefore, rates of current and historical parrot ownership could be ascertained only from information provided voluntarily by interviewees and should be considered a conservative estimate.

We did not provide interviewees with a definition of a pet parrot, and individuals reported on both caged and uncaged birds. We anticipated a priori, given the physical similarities between the two Coracopsis spp., that it would be difficult for urban respondents to differentiate between $C$. nigra and $C$. vasa, especially if they saw the pet parrot only briefly. Therefore, aside from differentiating between Coracopsis spp. and A. canus (based on the respondent's use of local or scientific names) no further species identification was done. We did not provide images of birds to facilitate species identification. When an interviewee did not recognize the common names used by researchers, we occasionally showed photographs of the three species on mobile phones.

\section{Analysis}

Following similar studies (Reuter et al., 2016), and as there may be greater variation between than within towns, interviewees were used as subsamples within each town except for subsets of the data with low sample size. In other words, towns were used as replicates in analyses unless otherwise noted. Results are presented as mean values with $95 \%$ confidence intervals.

We estimated the total number of Coracopsis spp. held in urban households during 2015 to mid 2016 by extrapolating 
TABLE 2 Towns in Madagascar where interviews were conducted (Fig. 1), with population, number of households interviewed, percentage of individuals who knew someone who owned or had previously owned a parrot, and percentage of individuals who themselves owned or had previously owned a parrot. Population estimates for cities were obtained from the Ilo Project (2003).

\begin{tabular}{lllll}
\hline Town & Population & $\begin{array}{l}\text { No. of households } \\
\text { interviewed }(\%)\end{array}$ & $\begin{array}{l}\text { \% interviewees who } \\
\text { had seen a pet parrot }\end{array}$ & $\begin{array}{l}\text { \% interviewees who were current } \\
\text { or former parrot owners }\end{array}$ \\
\hline Ambositra & 32,818 & $62(0.83)$ & 48 & 21 \\
Andasibe & 12,000 & $53(1.94)$ & 11 & 17 \\
Antananarivo & $1,054,649$ & $53(0.02)$ & 23 & 11 \\
Antsirabe & 186,253 & $25(0.06)$ & 68 & 0 \\
Beforona & 13,000 & $55(1.86)$ & 38 & 6 \\
Fianarantsoa & 126,000 & $32(0.11)$ & 25 & 7 \\
Moramanga & 40,050 & $60(0.66)$ & 55 & 0 \\
Toamasina (Tamatave) & 201,729 & $50(0.11)$ & 36 & 6 \\
Tôlanaro (Fort Dauphin) & 46,298 & $50(0.48)$ & 32 & 8 (95\% CI 3-15) \\
Total & $1,712,797$ & $440(0.11)$ & $37(95 \%$ CI 26-48) & \\
\hline
\end{tabular}

${ }^{\star}$ Does not include the respondents who had personally owned a parrot.

the frequency of bird ownership at our urban sites to the towns in which data were collected, and also to all urban areas in Madagascar. Following Reuter et al. (2016), we assumed conservatively that only one bird was owned per individual, representing one household.

\section{Results}

Profile of interviewees Most (6o\%) interviewees were female, $34 \%$ were male, and data were not collected in the remaining $6 \%$ of interviews (gender recorded in 412 interviews). All were adults over the age of 18 .

Geographical extent of ownership Pet parrots had been seen by respondents in all administrative regions where interviews were conducted. They had also been seen elsewhere in the country (Fig. 2).

Proportion of respondents who had seen or owned parrots Many interviewees (37\% (95\% CI $16-48 \%) ; \mathrm{n}=161$ over nine towns) had seen pet Coracopsis spp. (Table 2). The proportion of interviewees who had seen a pet Coracopsis sp. varied by town (Pearson $\chi^{2}$ test: $\chi^{2}=44.519, \mathrm{~N}=440, \mathrm{df}=8$, $\mathrm{P}<0.0001$ ). In addition, $8 \%$ (95\% $\mathrm{CI}_{3}-13 \%$ ) of interviewees per town (range $0-21 \%$ ) had personally owned a pet Coracopsis sp. previously. Sample sizes $(\mathrm{n}=39$ owners across nine towns) were too small to test whether the proportion of interviewees who had owned a pet Coracopsis sp. varied by town. In the nine towns surveyed, $2.3 \%$ (95\% CI 0.1-4.5\%) of individuals interviewed had owned a pet Coracopsis sp. in the 1.5 years prior to the interview (in 2015 and 2016). An extrapolation suggests that an estimated 1,290 Coracopsis spp. individuals were held in captivity in the towns surveyed, in the 1.5 years prior to our interview (using town-specific rates of ownership for extrapolation). Extrapolating the $2.3 \%$ (95\% CI $0.1-4.5 \%$ ) estimate to all urban households in Madagascar yields an estimate of
38,002 (95\% CI 1,652-74,352) Coracopsis spp. individuals being held in captivity across the country in the 1.5 years prior to our interview. Fewer interviewees $(n=20$, or $4.5 \%$ of all interviewees) had seen an A. canus in captivity. Only one individual interviewed reported having previously owned an A. canus.

Timing of ownership Most people (75\% of 161 individuals) and most owners ( $79 \%$ of 39 owners) could recall the year in which they saw or owned a pet Coracopsis sp. Most people (66\% of 20 individuals) could recall the year in which they saw a pet $A$. canus, as could the one owner of this species interviewed. Many of these encounters occurred in the previous 10 years (Table 2). At least one respondent reported having seen pet Coracopsis spp. in every decade since the 1970 s and pet $A$. canus in every decade since the 1980 s. Respondents reported owning Coracopsis spp. in every decade since the 1980s, and the one owner of A. canus reported owning the pet in 2014 .

\section{Discussion}

\section{Extent and patterns of ownership}

Based on our study and extrapolation to other urban areas of Madagascar we estimate that 1,290 Coracopsis spp. individuals were held in captivity in the towns surveyed, in the 1.5 years prior to our interviews. For context, 10,117 Coracopsis spp. individuals were exported from Madagascar during 1981-2006 (UNEP-WCMC, 2016). As mentioned in published reports, the domestic pet trade could be less of a threat nationally than habitat degradation (CITES, 2008) and hunting (Dowsett, 2000; Ekstrom, 2004); more research on this topic is required. Ownership of $A$. canus was relatively low; so low that we could not extrapolate to the rest of Madagascar. Overall, the frequency of 

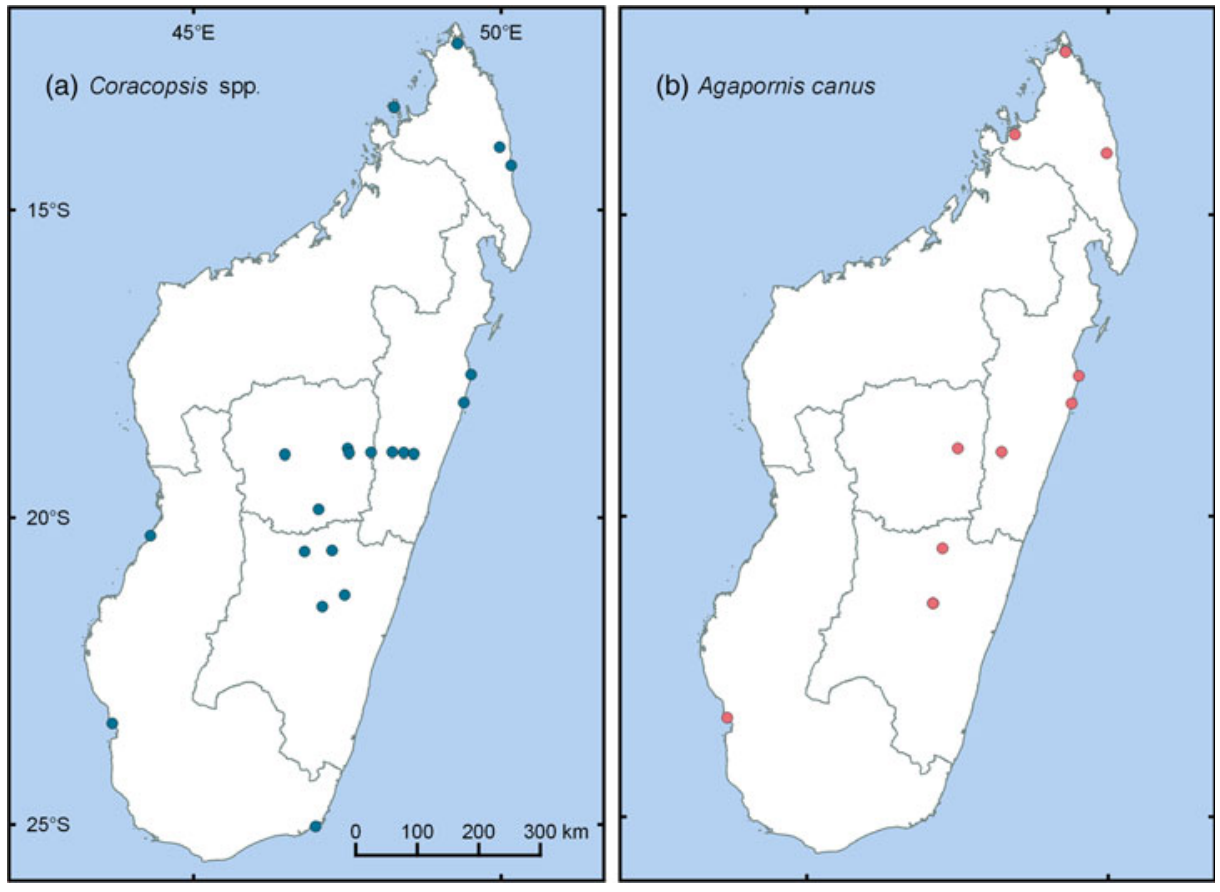

FIG. 2 Locations in Madagascar where interviewees reported seeing (a) Coracopsis spp. and (b) Agapornis canus individuals kept as pets. pet parrot ownership in Madagascar (8\% (95\% CI 3-13\%) of households) may be low compared to other countries ( $18 \%$ of Costa Rican households have kept parrots as pets, Drews, 2001; $21.8 \%$ of Indonesian households surveyed had pet birds, Jepson \& Ladle, 2009), although it appears to be high in some towns.

The ownership of pet parrots appears to be widespread in time and space, but more extensive surveys are required to investigate the hotspots of ownership. We found evidence of in-country ownership of Coracopsis spp. and A. canus going back several decades. In similar, recent research on the incountry ownership of lemurs, respondents could recall seeing captive lemurs in Madagascar in the 1960s (Reuter et al., 2016).

Although not indicated directly by our dataset, our findings indicate that compared to the ownership of pet lemurs, the ownership of pet parrots is relatively visible in urban areas of Madagascar. This is the case even though most of the observed parrot ownership would probably be considered illegal. Perhaps this reflects a low awareness regarding environmental laws in Madagascar (Keane et al., 2011), poor enforcement of laws, and/or that ownership is not associated with social stigma. Over one-third of respondents reported having seen a Coracopsis sp. as a pet, and we saw parrots kept in cages on balconies of households that were not selected for interviews. Unlike when conducting surveys related to the illegal ownership of lemurs (Reuter et al., 2016), we did not sense a fear of enforcement or repercussions as a consequence of participation in the survey. Respondents did not hesitate to show researchers their pet parrots, and self-reported ownership rates were up to $21 \%$ of interviewees in some towns (Table 2). In one case, a pet parrot was owned collectively by the staff of a police station.

\section{Conservation implications}

We cannot ascertain whether the in-country ownership of pet parrots is sustainable, because there is a lack of published information about these species (e.g. population estimates) and their ownership as pets (e.g. longevity in captivity, age of capture). As such, we cannot estimate extraction rates for these species. Information on longevity in captivity and age of capture would be a useful avenue for future studies. In a well-kept captive environment, the maximum lifespan in captivity has been reported as 38,29 and 16 years for C. nigra, C. vasa and A. canus, respectively (Young et al., 2012). Therefore, the parrots could conceivably be moved among and between multiple owners over time. However, in Madagascar, Coracopsis spp. may be kept in captivity for much shorter periods of time (K. Reuter et al., unpubl. data), perhaps because (as we observed anecdotally) pet parrots are kept in environments that do not facilitate adequate movement and nutrition. Regarding the age of capture, unlike studies from elsewhere (e.g. Jepson, 2003), we do not know whether there is a tendency to catch wild parrots at certain life stages (e.g. young, crop-raiding birds or breeding adults), although both adults and juveniles of C. vasa and $A$. canus are reportedly captured as pets (BirdLife International, 2017a,b). Should the extraction of parrots for the pet trade be unsustainable, the resulting decrease in parrot populations could have negative implications for 
ecosystem health. In several remnant forests in Madagascar, C. vasa and C. nigra are among only a few frugivorous bird species (Bollen \& Elsacker, 2004; Reuter, 2015). As such, they are considered to be important seed dispersers (Reuter, 2015). In other areas of the developing world, market-based solutions (such as commercial breeding of popular bird species) have been proposed to shift bird-keeping from wildcaught to captive-bred individuals (Jepson \& Ladle, 2009; Jepson et al., 2011). These market-based and voluntary mechanisms are recommended in areas where stricter regulations are impractical (Jepson \& Ladle, 2009) and where trade bans may not be effective (Cooney \& Jepson, 2006), such as is the case in Madagascar.

Additional studies on these species are important for Madagascar to meet the conditions of international agreements such as those on biodiversity conservation and trade. Madagascar is party to CITES (1983) and the Convention on Biological Diversity (United Nations, 1992) and has therefore agreed to regulate aspects of wild animal trade using national legislation and governance. In relation to the Convention on Biological Diversity, 'the use of components of biological diversity' is required 'in a way and at a rate that does not lead to long-term decline of biological diversity' (CBD, 1992). Regarding CITES, although the listing of parrot species on Appendix II (CITES, 2017) is the motivation for international and domestic trade regulations, our findings suggest that domestic regulations are not currently effective in monitoring or enforcing limits on extraction of the species from the wild. Therefore, an analysis of Madagascar's legal frameworks on trade and tenure of wildlife, enforcement policies and results, and the country's international commitments, especially regarding parrots, is warranted.

\section{Acknowledgements}

We thank the reviewers whose feedback substantially improved the quality of the article; Groupe d'étude et de recherche sur les primates de Madagascar, Association Mitsinjo, Sainte Luce Reserve, and Conservation International for facilitating research; Tiana Ratolojanahary, Irène Ramanantenasoa, Housseini Maihidini, Tokihenintsoa Andrianjohaninarivo and Tolotra Fanambinantsoa for serving as translators; Toby Schaeffer for the development of maps; and host communities for their hospitality. This research was funded by a National Geographic Conservation Trust grant to KER.

\section{Ethical statement}

Research was approved by the University of Utah Institutional Review Board, followed national and local laws, and was authorized by locally elected officials in every town and commune where research took place. This research did not require government research permits.

\section{Author contributions}

KER and MSS designed the project, and KER secured funding. All authors collected, analysed and interpreted data, wrote and undertook a critical revision of the article, and approved the final article for publication.

\section{References}

Andreone, F., Cadle, J.E., Cox, N., Glaw, F., Nussbaum, R.A., Raxworthy, C.J. et al. (2005) Species review of amphibian extinction risks in Madagascar: conclusions from the Global Amphibian Assessment. Conservation Biology, 19, 1790-1802.

Annorbah, N.N.D., Collar, N.J. \& Marsden, S.J. (2016) Trade and habitat change virtually eliminate the grey parrot Psittacus erithacus from Ghana. Ibis, 158, 82-91.

Baillie, J.E.M., Hilton-Taylor, C. \& Stuart, S.N. (eds) (2004) IUCN Red List of Threatened Species. A Global Species Assessment. IUCN, Gland, Switzerland, and Cambridge, UK.

Bird Life International (2016a) Agapornis canus. In The IUCN Red List of Threatened Species 2016: e.T22685326A93068058. Http://dx. doi.org/10.2305/IUCN.UK.2016-3.RLTS.T22685326A93068058.en [accessed 21 January 2017].

BirdLife International (2016b) Coracopsis nigra. In The IUCN Red List of Threatened Species 2016: e.T22727885A94964612. Http://dx. doi.org/10.2305/IUCN.UK.2016-3.RLTS.T22727885A94964612.en [accessed 21 January 2017].

BirdLife International (2016c) Coracopsis vasa. In The IUCN Red List of Threatened Species 2016: e.T22685261A93065700. Http://dx. doi.org/10.2305/IUCN.UK.2016-3.RLTS.T22685261A93065700.en [accessed 21 January 2017].

Bird Life International (2017a) Species factsheet: Agapornis canus. Http://www.birdlife.org [accessed 21 January 2017].

BirdLife International (2017b) Species factsheet: Coracopsis vasa. Http://www.birdlife.org [accessed 21 January 2017].

Bollen, A. \& Donati, G. (2006) Conservation status of the littoral forest of south-eastern Madagascar: a review. Oryx, 40, 57-66.

Bollen, A. \& Elsacker, L.V. (2004) The feeding ecology of the lesser vasa parrot, Coracopsis nigra, in south-eastern Madagascar. Ostrich, $75,141-146$.

CBD (Convention on Biological Diversity) (1992) Text of the Convention on Biological Diversity. CBD Secretariat, Montreal, Canada.

CITES (1983) Convention on International Trade in Endangered Species of Wild Fauna and Flora. Https://cites.org/sites/default/files/ eng/disc/CITES-Convention-EN.pdf [accessed 5 December 2016].

CITES (2008) Interpretation and Implementation of the Convention. Species Trade and Conservation. Review of Significant Trade. SC 57 Doc 29.2. Fifty-seventh meeting of the Standing Committee, Geneva, Switzerland.

CITES (2017) The CITES Appendices. Http://www.cites.org/eng/app/ index.shtml [accessed 26 June 2017].

Collar, N.J. (1997) Family Psittacidae (parrots). In Handbook of the Birds of the World. Volume 4: Sandgrouse to Cuckoos (eds J. del Hoyo, A. Elliott \& J. Sargatal), pp. 280-477. Lynx Edicions, Barcelona, Spain.

Cooney, R. \& Jepson, P. (2006) The international wild bird trade: what's wrong with blanket bans? Oryx, 40, 18-23.

Dillman, J.D. (2014) Covering the population and selecting who to survey. In Internet, Phone, Mail, and Mixed-Mode Surveys: The Tailored Design Method, 4 th edition (eds D.A. Dillman, J.D. Smyth \& L. M. Christian), pp. 56-93. Wiley, Somerset, USA. 
Dowsett, R.J. (2000) Le statut des Perroquets vasa et noir Coracopsis vasa et C. nigra et de l'inséparable à tête grise Agapornis canus à Madagascar. IUCN Species Survival Commission, Cambridge, UK. Drews, C. (2001) Wild animals and other pets kept in Costa Rican households: incidence, species and numbers. Society \& Animals, 9, 107-126.

Durbin, J. (2007) New legislation for the protection of Malagasy species. Lemur News, 11, 4-6.

Eкsтrom, J.M.M. (2004) Psittaciformes: Coracopsis spp., parrots. In The Natural History of Madagascar (eds S.M. Goodman \& J.P. Benstead), pp. 1098-1102. University of Chicago Press, Chicago, USA.

Golden, C.D., Bonds, M.H., Brashares, J.S., Rasolofoniaina, B.J. R. \& Kremen, C. (2014) Economic valuation of subsistence harvest of wildlife in Madagascar. Conservation Biology, 28, 234-243.

Hart, J., Hart, T., Salumu, L., Bernard, A., Abani, R. \& Martin, R. (2016) Increasing exploitation of grey parrots in eastern DRC drives population declines. Oryx, 50, 16.

Ilo Project (2003) Recensement des Communes 2001. Http://www. ilo.cornell.edu/ilo/data.html [accessed 12 July 2017].

instat (Institut National de la Statistique) \& ORC Macro (2005) Enquête Démographique et de Santé, Madagascar 2003-2004: Rapport de synthèse. INSTAT and ORC Macro, Calverton, USA.

JEPSON, P. (2003) The need for a better understanding of context when applying CITES regulations: the case of an Indonesian parrot-Tanimbar corella. In The Trade in Wildlife: Regulation for Conservation (ed. S. Oldfield), pp. 153-162. Earthscan, London, UK.

Jepson, P. \& Ladle, R.J. (2009) Governing bird-keeping in Java and Bali: evidence from a household survey. Oryx, 43, 364-374.

Jepson, P., Ladle, R.J. \& Sujatnika(2011) Assessing market-based conservation governance approaches: a socio-economic profile of Indonesian markets for wild birds. Oryx, 45, 482-491.

Karesh, W.B., Cook, R.A., Bennett, E.L. \& Newcomb, J. (2005) Wildlife trade and global disease emergence. Emerging Infectious Diseases, 11, 1000-1002.

Keane, A., Ramarolahy, A.A., Jones, J.P.G. \& Milner-Gulland, E.J. (2011) Evidence for the effects of environmental engagement and education on knowledge of wildlife laws in Madagascar. Conservation Letters, 4, 55-63.

Martin, R.O., Perrin, M.R., Boyes, R.S., Abebe, Y.D., Annorbah, N.D., Asamoah, A. et al. (2014) Research and conservation of the larger parrots of Africa and Madagascar: a review of knowledge gaps and opportunities. Ostrich, 85, 205-233.

McBride, P. (1996) Concern for the greater vasa parrot. Psitta-Scene, 8,10 .

Pires, S.F. (2012) The illegal parrot trade: a literature review. Global Crime, 13, 176-190.

Poole, C.M. \& Shepherd, C.R. (2017) Shades of grey: the legal trade in CITES-listed birds in Singapore, notably the globally threatened African grey parrot Psittacus erithacus. Oryx, 51, 411-417.
Randrianandrianina, F.H., Racey, P.A. \& Jenkins, R.K.B. (2010) Hunting and consumption of mammals and birds by people in urban areas of western Madagascar. Oryx, 44, 411-415.

Reuter, K.E. (2015) Natural resource use in Madagascar. Doctoral dissertation. Temple University, Philadelphia, USA.

Reuter, K.E., Gilles, H., Wills, A.R. \& Sewall, B.J. (2016) Live capture and ownership of lemurs in Madagascar: extent and conservation implications. Oryx, 50, 344-354.

Schwitzer, C., King, T., Robsomanitrandrasana, E., Chamberlan, C. \& Rasolofoharivelo, T. (2013) Integrating ex situ and in situ conservation of lemurs. In Lemurs of Madagascar: A Strategy for their Conservation 2013-2016 (eds C. Schwitzer, R. A. Mittermeier, N. Davies, S. Johnson, J. Ratsimbazafy, J. Razafindramanana et al.), pp. 146-152. IUCN SSC Primate Specialist Group, Bristol Conservation and Science Foundation, and Conservation International, Bristol, UK.

Species Survival Network (2001) History of Species Reviewed under Resolution Conf. 89 (Rev.). Species Survival Network, Washington, DC, USA.

UNDP (2013) Human Development Report 2013: The Rise of the South: Human Progress in a Diverse World. United Nations Development Programme, New York, USA.

UNEP-WCMC (2016) CITES Trade Statistics Derived from the CITES Trade Database. UNEP World Conservation Monitoring Centre, Cambridge, UK. Http://trade.cites.org/ [accessed 2 December 2016].

United Nations (1992) Convention on Biological Diversity. Paper presented at Rio Earth Summit. Rio de Janeiro. Https://www.cbd. int/doc/legal/cbd-en.pdf [accessed 2 December 2016].

Watson, J.E.M., Whittaker, R.J. \& Dawson, T.P. (2004) Habitat structure and proximity to forest edge affect the abundance and distribution of forest-dependent birds in tropical coastal forests of southeastern Madagascar. Biological Conservation, 120, 311-327.

Wildlife Trade Tracker (2016) Http://wildlifetradetracker.org/ [accessed 12 July 2017].

WORLD BANK (2016) Http://data.worldbank.org/indicator/SP.POP. TOTL?locations=MG [accessed 12 July 2017].

Young, A.M., Hobson, E.A., Lackey, L.B. \& Wright, T.F. (2012) Survival on the ark: life-history trends in captive parrots. Animal Conservation, $15,28-43$.

\section{Biographical sketches}

KIm ReUter's interests include the wildlife trade, natural resource use, and conservation in sub-Saharan Africa. Lucia RODRIgUez is interested in the psychology of environmental conservation and community-level outreach. SA H ONDR A HANITRINI A IN A has done research on Madagascar's insect communities and on the bushmeat trade. Melissa SCHAEFER's research focuses on both captive and wild primates as well as subfossil primates. 